\title{
The prognostic impact of decreased pretreatment haemoglobin level on the survival of patients with lung cancer: a systematic review and meta-analysis
}

Yaqi Huang ${ }^{1 \dagger}$, Siqi Wei ${ }^{1+}$, Nan Jiang ${ }^{1 \dagger}$, Lijuan Zhang ${ }^{2}$, Siyuan Wang ${ }^{1}$, Xiaona Cao ${ }^{1}$, Yue Zhao ${ }^{1 *}$ (D) and Peiguo Wang ${ }^{3^{*}}$

\begin{abstract}
Background: Many studies have reported the prognostic value of haemoglobin level for cancers. Whereas the prognostic impact of decreased pretreatment haemoglobin level on the survival of patients with lung cancer remains controversial, herein, a systematic review and meta-analysis were conducted to investigate whether a decreased haemoglobin level before treatment is a significant predictor of survival in patients with lung cancer.
\end{abstract}

Methods: We performed a systematic review and meta-analysis of observational studies to evaluate the prognostic impact of a decreased haemoglobin level on the survival of patients with lung cancer. Relevant studies were retrieved from databases including PubMed, Embase, Web of Science and the Cochrane Library. Reference lists were hand-searched for potentially eligible studies. The Newcastle-Ottawa scale was used to assess the quality of included studies. Observational studies were included if they provided sufficient information for the extraction of the pooled hazard ratios (HR) and 95\% confidence intervals $(95 \% \mathrm{Cl})$ for overall survival, disease-free survival, relapse-free survival, progression-free survival, eventfree survival and time to progression. Subgroup analysis, meta-regression and sensitivity analyses were applied to explain the heterogeneity.

Results: Fifty-five articles involving a total of 22,719 patients were obtained to evaluate the correlation between haemoglobin level and survival. The results indicated that decreased haemoglobin level was significantly associated with poor overall survival of patients with lung cancer (HR 1.51,95\% Cl 1.42-1.61), both in non-small cell lung cancer (HR 1.57, 95\% Cl 1.44-1.72) and in small cell lung cancer (HR 1.56, 95\% Cl 1.21-2.02). We also found that the lower the haemoglobin level, the shorter was the overall survival of patients with lung cancer (HR 1.11,95\% Cl 1.06-1.16). However, the relationship between decreased haemoglobin and relapse-free survival was not significant (HR 1.37, 95\% Cl 0.91-2.05).

Conclusion: A decreased pretreatment haemoglobin level among patients with lung cancer is a prognostic factor of poor survival that can serve as an important indicator in survival prediction, risk stratification and treatment selection. In clinical practice, more attention should be paid to monitoring pretreatment haemoglobin levels among patients with lung cancer.

Keywords: Lung cancer, Haemoglobin, Prognosis, Meta-analysis

\footnotetext{
* Correspondence: yuezhaotjmedu@163.com; PGW_2017@163.com

†Yaqi Huang, Siqi Wei and Nan Jiang contributed equally to this work.

'School of Nursing, Tianjin Medical University, Tianjin 300070, China

${ }^{3}$ Department of Radiotherapy, Tianjin Medical University Cancer Institute and

Hospital, National Clinical Research Center for Cancer, Tianjin 300060, China

Full list of author information is available at the end of the article
}

(c) The Author(s). 2018 Open Access This article is distributed under the terms of the Creative Commons Attribution 4.0 International License (http://creativecommons.org/licenses/by/4.0/), which permits unrestricted use, distribution, and reproduction in any medium, provided you give appropriate credit to the original author(s) and the source, provide a link to the Creative Commons license, and indicate if changes were made. The Creative Commons Public Domain Dedication waiver (http://creativecommons.org/publicdomain/zero/1.0/) applies to the data made available in this article, unless otherwise stated. 


\section{Background}

Lung cancer is the most prevalent cancer and the leading cause of cancer-related death in both men and women [1, 2]. Although integrated treatment strategies and multidisciplinary nursing interventions based on surgery, radiotherapy and chemotherapy have provided improvements in the survival of patients with lung cancer, more effective prognostic factors should be identified to guide therapy and assess disease progression in individuals. In previous studies, the tumour-node-metastasis (TNM) staging system and tumour markers have made great contributions to the prediction of clinical outcomes, though most of these markers are clinicopathological parameters determined after surgery and are associated with high costs. Thus, it is important to detect new predictors to satisfy clinical requirements $[3,4]$.

Decreased haemoglobin $(\mathrm{Hb})$ is the most commonly observed haematological abnormality in patients with cancers; it is induced by the direct or the indirect effects of malignancy or its treatment [5]. The National Comprehensive Cancer Network considered that $\mathrm{Hb}$ levels less than $11 \mathrm{~g} / \mathrm{dl}$ can be diagnostic of cancer-related decreased $\mathrm{Hb}$ [6]. The mechanism of $\mathrm{Hb}$ degradation in lung cancer is complex. Blood loss, haemolysis, marrow infiltration and nutritional deficiencies may all be responsible for the development of $\mathrm{Hb}$ decline. Cancer-stimulated production of inflammatory cytokines (e.g. TNF- $\alpha$, IL-1, IL-6, INF- $\gamma$ ) can inhibit erythropoiesis resulting in $\mathrm{Hb}$ reduction $[7,8]$. The Hb level is a convenient and well-known parameter in clinical practice. An increasing body of evidence indicates that decreased $\mathrm{Hb}$ is related to poor prognosis in cancers $[4,9,10]$. However, the prognostic value of $\mathrm{Hb}$ level in patients with lung cancer has not been well confirmed. Numerous previous studies that have examined this relationship provide conflicting results [11-14]. Some studies showed that overall survival (OS) was significantly shorter in lung cancer patients with a low $\mathrm{Hb}$ level before treatment $[11,12]$, while some showed that the correlation between low $\mathrm{Hb}$ level and shorter $\mathrm{OS}$ was not significant $[13,14]$. Therefore, in this study, a meta-analysis was conducted to determine the prognostic value of decreased $\mathrm{Hb}$ level in patients with lung cancer.

\section{Method}

\section{Search strategy}

Relevant studies that referred to the prognostic value of the $\mathrm{Hb}$ level in patients with lung cancer were identified by searching several databases up to November 2017, including PubMed, Embase, Web of Science and Cochrane Library. We used the following terms as $\mathrm{MeSH}$ terms and free-text terms ('lung neoplasm,' 'lung cancer,' 'lung carcinoma, 'lung tumor'), ('hemoglobin,' 'Hb' 'hemoglobinometry', 'anemia') and ('mortality', 'prognosis', 'prognostic', 'predict', 'predictive,' 'predictor,' 'survival', 'outcome'); only studies published in English were retrieved. The references of candidate studies were also reviewed.

\section{Inclusion and exclusion criteria}

The identified studies were independently selected by two reviewers following the inclusion and exclusion criteria below. Disagreements were discussed in a group to reach consensus. Studies were included if they met the following criteria: (1) The study population was patients who were diagnosed with lung cancer; (2) The serum $\mathrm{Hb}$ level was measured before treatment; (3) The relationship between the $\mathrm{Hb}$ level and survival was provided; and (4) A univariate Log-rank test or multivariate Cox proportional hazards model was used for statistical analysis; only observational studies were selected. Studies were excluded if they met one of the following criteria: (1) Studies were not published in English; (2) The full-text could not be obtained; (3) Data were not sufficient to extract the hazard ratio (HR) and 95\% confidence interval (CI); and (4) Survival data were only provided as Kaplan-Meier curves; repeated studies or duplicate data were excluded. If one author reported the same population in different articles, only the most detailed one was included.

\section{Quality assessment}

Two reviewers evaluated the quality of each study independently. The Newcastle-Ottawa scale (NOS) was used to assess the quality of included studies. The scale contains 8 items in 3 dimensions (selection, comparability and outcome) [15]. The assessment was carried out by awarding stars for high-quality studies, ranging from zero up to nine stars. A score of more than 6 stars indicates a high quality [16].

\section{Data extraction}

Two reviewers extracted data from the eligible studies independently. Any discrepancy in data extraction was resolved through a cross-check and discussion. The primary data extracted were HR for poor prognosis with 95\% CI, or the data necessary to calculate the HR and 95\% CI. HRs from multivariate analyses were extracted if both univariate and multivariate analyses were provided. The characteristics of the studies and patients were collected, including the first author, year published, country, number of patients, gender, mean or median age of patients, duration of follow-up, subtype of lung cancer, stage of the tumour, treatment modalities, Hb cut-off value, indicator of survival analysis, and statistical methods.

\section{Statistical analysis}

All statistical analyses were performed with Stata statistical software, version 15.0 (Stata Corp LLC, College Station, TX, USA). The association between $\mathrm{Hb}$ level and 
prognosis of patients with lung cancer was estimated by calculating the pooled $\mathrm{HR}$ and $95 \% \mathrm{CI}$. We used the random-effect model to combine the effective value based on heterogeneity [17]. A $p$ value $<0.05$ was considered to be significant in all statistical tests. HR $>1$ indicated a negative prognosis in patients with a low $\mathrm{Hb}$ level. The heterogeneity of the pooled HRs was assessed using the Cochran's $Q$ test and $I^{2}$ test, and a $p$ value less than 0.05 or an $I^{2}$ more than $50 \%$ was considered to be statistically significant [18]. To explain heterogeneity, subgroup analyses were performed by stratifying the included studies by lung cancer subtype and statistical method. To further explore the sources of heterogeneity, meta-regression analyses were conducted. We also performed sensitivity analyses by deleting one study at a time to estimate the contribution of included studies to heterogeneity. Egger's indicator test and Begg's funnel plot were applied to scrutinize publication bias $[19,20]$.

\section{Result}

\section{Study retrieval}

A total of 5723 citations were retrieved using the search strategy described above. Four hundred twelve duplicate records were removed. After screening and scanning the titles and abstracts of the publications, 5044 studies were excluded for being reviews, animal experiments, case reports, letters, comments, drug clinical trials, or otherwise irrelevant to our studies. After reviewing the full texts of 267 candidate studies, 213 articles were excluded according to the criteria above. Of these, 67 articles were excluded for being irrelevant to our study. For example, one study investigated the effect of abnormal $\mathrm{Hb}$ level $(<12 \mathrm{~g} / \mathrm{l}$ or $>18 \mathrm{~g} / \mathrm{l})$ on the prognosis of lung cancer instead of investigating decreased $\mathrm{Hb}$ specifically, and some studies focused on the relationship between outcomes and decreased $\mathrm{Hb}$ during therapy rather than pretreatment levels. Fifty-five articles were excluded for reporting insufficient data to calculate HR, 44 articles for not having full text available, 42 for being published in other languages, and 5 for being duplicate publications. Two additional non-duplicate studies were identified from study reference lists. Finally, a total of 56 studies including 22,719 patients were included in this meta-analysis. The detailed search process is shown in Fig. 1.

\section{Study characteristics}

The main characteristics of all eligible studies are shown in Table 1. Forty-eight studies were analysed with

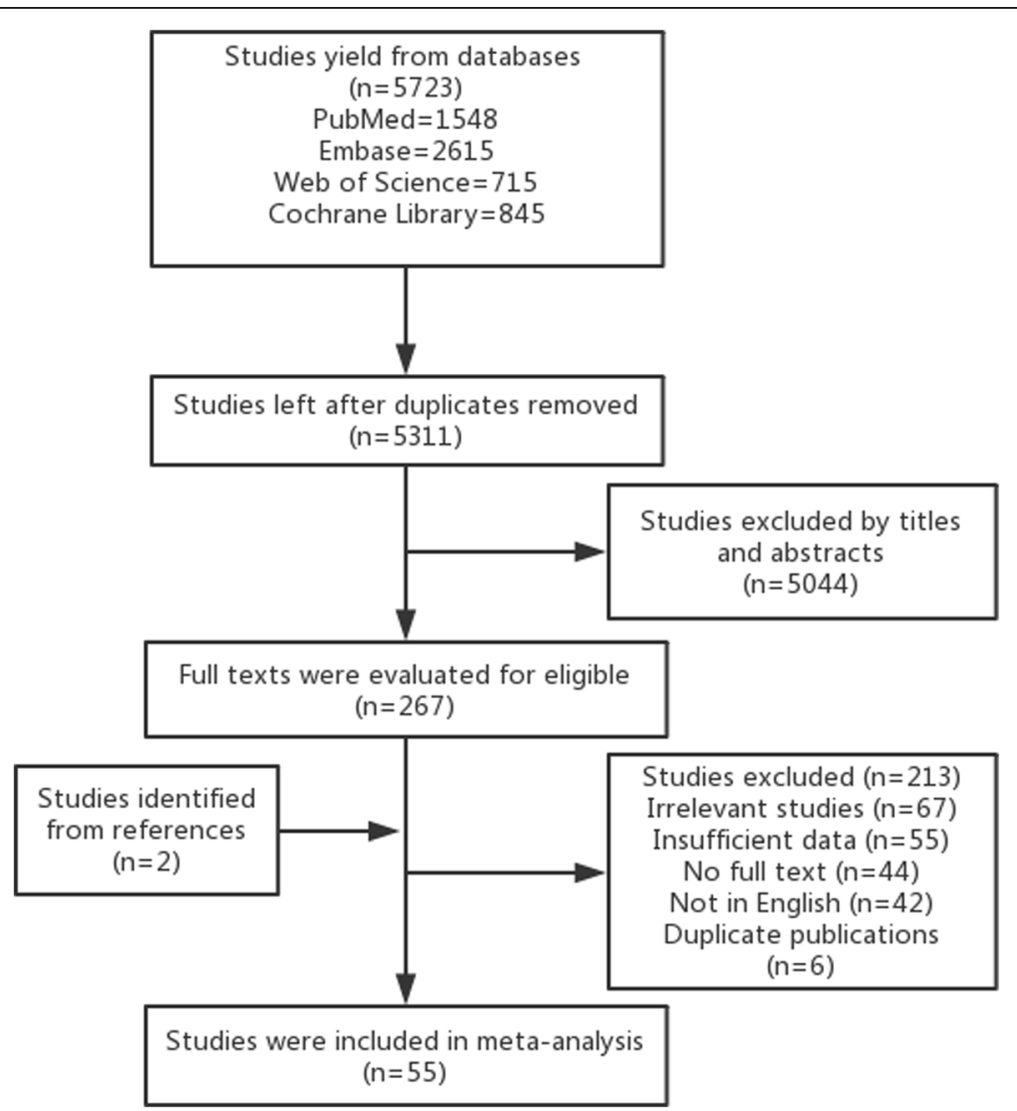

Fig. 1 Flow diagram following the searching strategy for studies included in this meta-analysis 


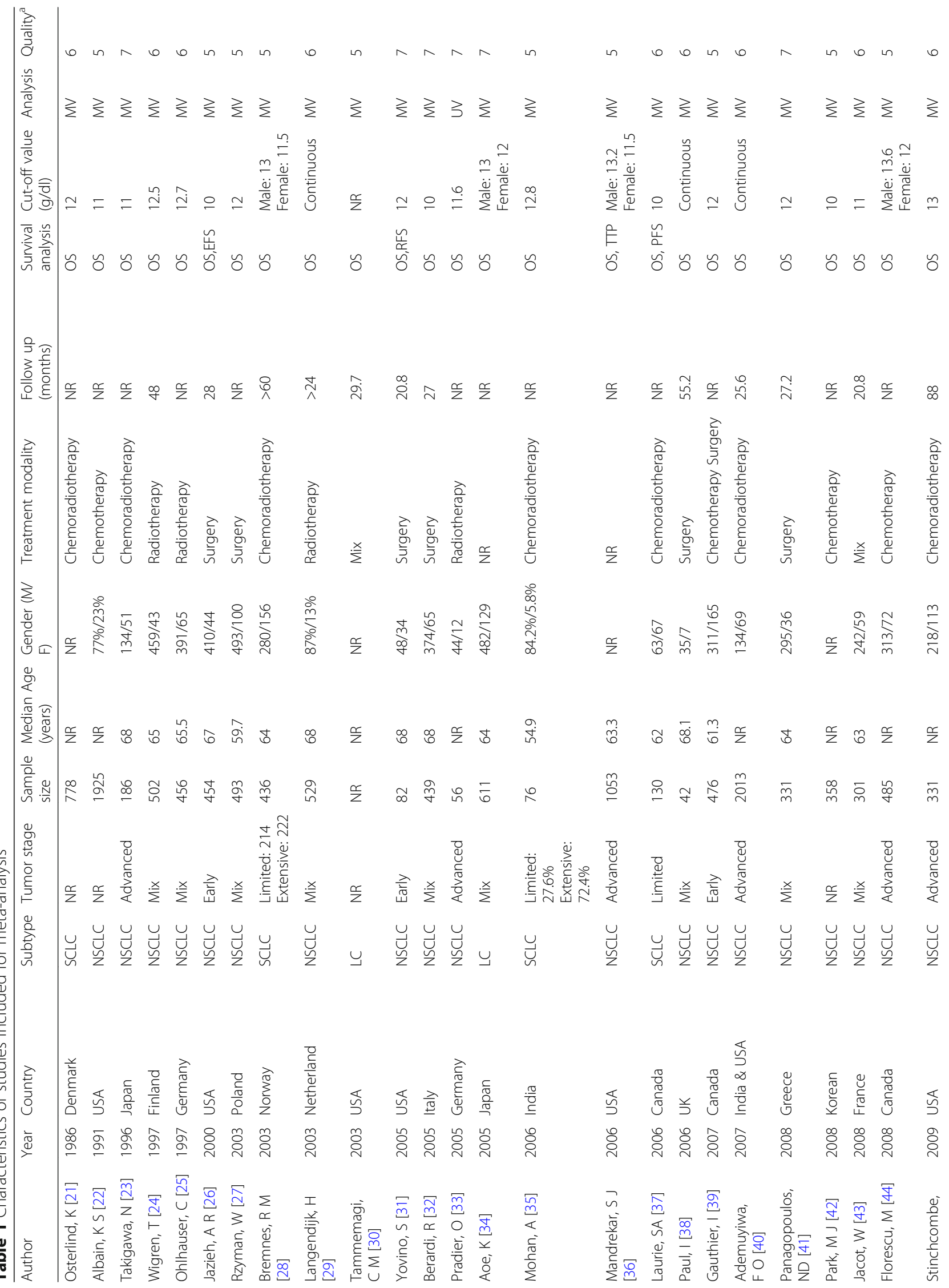




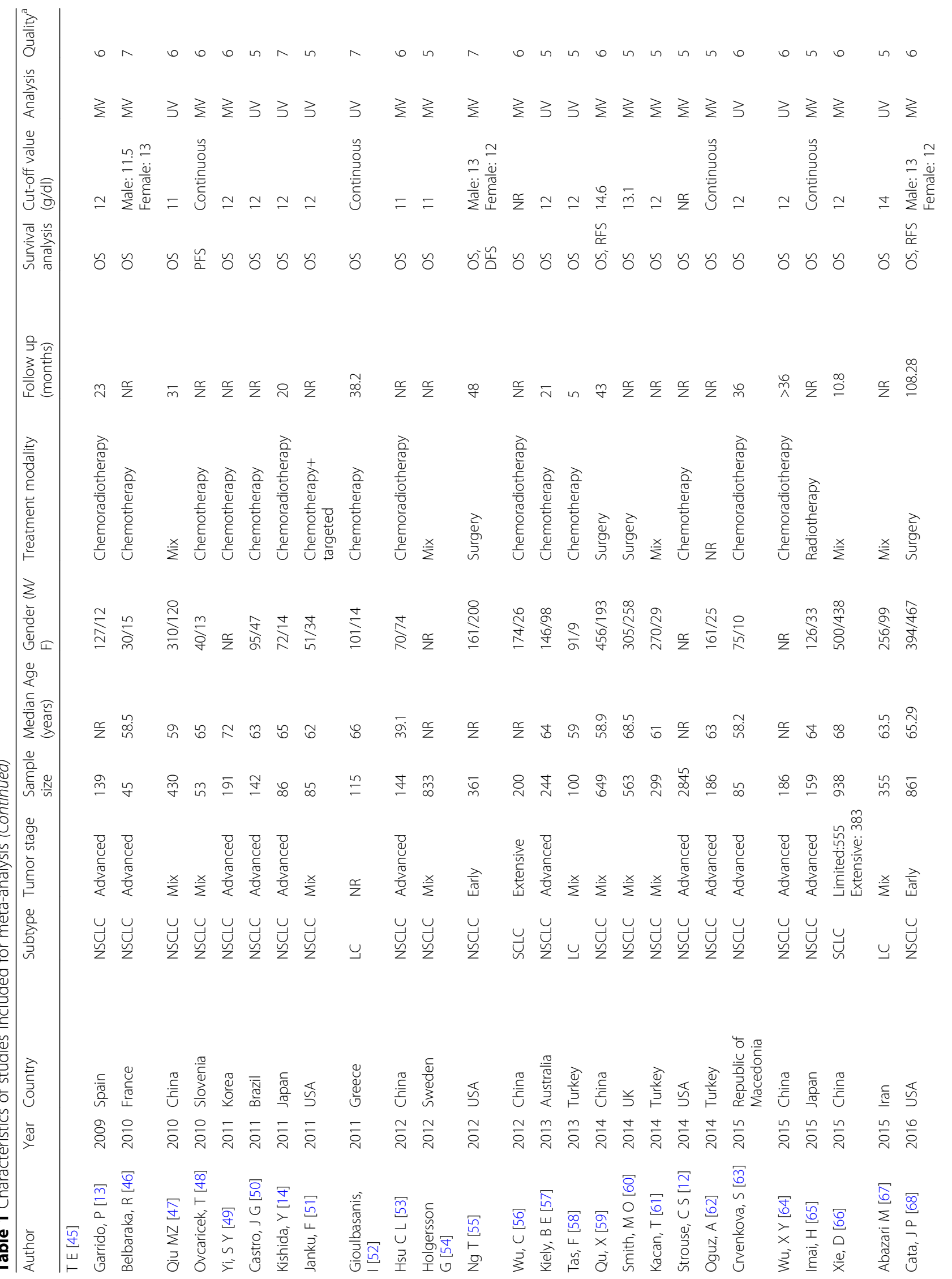




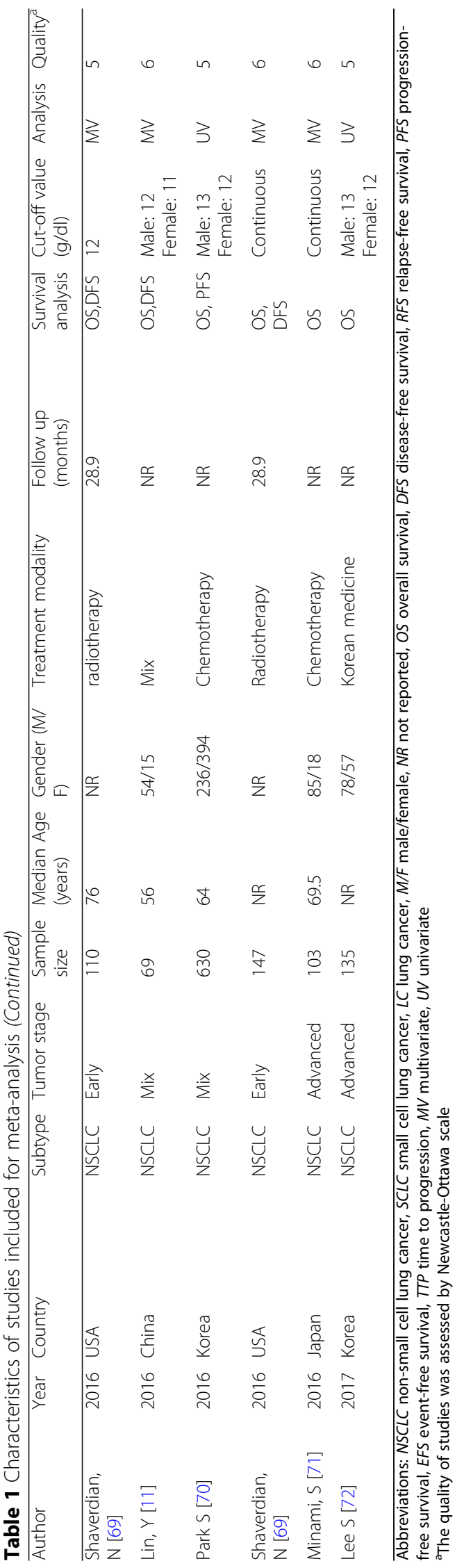


decreased $\mathrm{Hb}$ level as the categorical variable, 38 of which provided data on the relationship between $\mathrm{OS}$ and $\mathrm{Hb}$ in patients with non-small cell lung cancer (NSCLC); 6 studies were conducted in patients with small cell lung cancer (SCLC); and 4 studies included both patients with NSCLC and SCLC. Eight of the 56 included studies were analysed with pretreatment $\mathrm{Hb}$ as a continuous variable. Moreover, 3 studies were also available for disease-free survival (DFS), relapse-free survival (RFS) and progression-free survival (PFS) extraction, respectively. Only one study reported the relationship between the $\mathrm{Hb}$ level, event-free survival (EFS) and time to progression (TTP).

\section{$\mathrm{OS}$ and decreased $\mathrm{Hb}$}

Forty-eight articles with data on overall survival and decreased $\mathrm{Hb}$ (categorical variable: decreased $\mathrm{Hb}$ vs. normal $\mathrm{Hb}$ ) were included in the pooled analysis. There was significant heterogeneity among these studies $\left(I^{2}=39.1 \%, p=0.004\right)$, and thus, the random effect model was employed to calculate the pooled HR and its $95 \%$ CI. Lower $\mathrm{Hb}$ was significantly correlated with poor OS (HR 1.51, 95\% CI 1.42-1.61). For further exploration, subgroup analyses were conducted. Fortyeight studies were re-classified by "analysis method". In univariate analysis studies, there appeared to be no heterogeneity among HRs $\left(I^{2}=0.0 \%, p=0.517\right)$, and we found that decreased $\mathrm{Hb}$ was a negative prognostic factor for OS (HR 1.45, 95\% CI 1.29-1.63). Similarly, as shown in multivariate analyses, 36 studies also indicated that decreased pretreatment $\mathrm{Hb}$ predicted a significantly worse OS in patients with lung cancer (HR 1.53, 95\% CI 1.42-1.65) (Fig. 2).

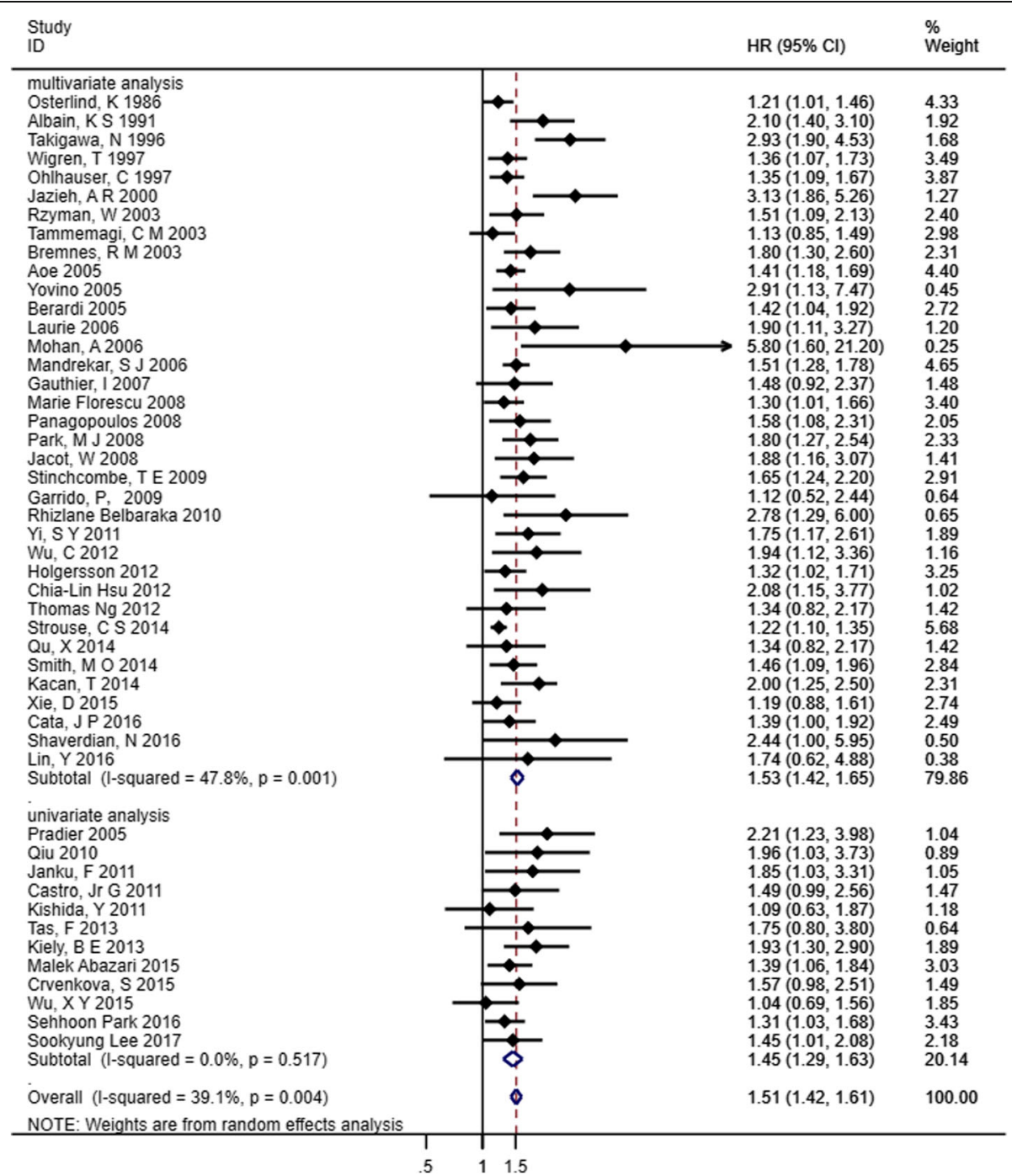

Fig. 2 Forest plot and pooled HR and 95\% Cl for OS in patients with lung cancer: pretreatment decreased $\mathrm{Hb}$ vs. normal $\mathrm{Hb}$. The pooled HR for OS showed that the patients with pretreatment decreased $\mathrm{Hb}$ level possessed a worse outcome in OS. HR hazard ratios, OS overall survival, Cl confidence interval, $\mathrm{Hb}$ hemoglobin 
Cut-off values of $10 \mathrm{~g} / \mathrm{dl}, 11 \mathrm{~g} / \mathrm{dl}$, and $12 \mathrm{~g} / \mathrm{dl}$, along with gender-specific values of $13 \mathrm{~g} / \mathrm{dl}$ (males) and $12 \mathrm{~g} / \mathrm{dl}$ (females), were mostly used in the included studies. We divided these studies into 4 subgroups based the $\mathrm{Hb}$ cut-off values used: $10 \mathrm{~g} / \mathrm{dl}, 11 \mathrm{~g} / \mathrm{dl}, 12 \mathrm{~g} / \mathrm{dl}$ and genderspecific (male $13 \mathrm{~g} / \mathrm{dl}$, female $12 \mathrm{~g} / \mathrm{dl}$ ). In total, the HRs of 32 studies were pooled in this meta-analysis. The results showed that decreased $\mathrm{Hb}$ before treatment was a significant predictor of OS in patients with lung cancer (HR 1.56, 95\% CI 1.43-1.70). Although the heterogeneity was still significant in the $11 \mathrm{~g} / \mathrm{dl}$ group $\left(I^{2}=71 \%, p=0.002\right)$, there was no significant heterogeneity overall or in the $10 \mathrm{~g} / \mathrm{dl}, 12 \mathrm{~g} / \mathrm{dl}$ and gender-specific (male $13 \mathrm{~g} / \mathrm{dl}$, female $12 \mathrm{~g} / \mathrm{dl}$ ) subgroups with $I^{2}$ of $35.5,55.3$ and $4.2 \%$, respectively (Fig. 3 ).

Eight cohorts analysed the $\mathrm{Hb}$ level data as a continuous variable and evaluated the correlation between pretreatment $\mathrm{Hb}$ level and OS. We found that a decreased $\mathrm{Hb}$ level was significantly related to OS (HR 1.11, 95\% CI 1.06-1.16) with no significant heterogeneity $\left(I^{2}=0.0 \%, p=0.770\right)$ (Fig. 4).

\section{Prognostic impact of decreased $\mathrm{Hb}$ on patients with NSCLC}

Twenty-eight studies evaluated the prognostic impact of decreased $\mathrm{Hb}$ (categorical variable: decreased $\mathrm{Hb}$ vs. normal $\mathrm{Hb}$ ) on NSCLC in multivariate analyses. We found that decreased $\mathrm{Hb}$ was a poor prognostic marker for OS (HR 1.57, 95\% CI 1.44-1.72) with moderate heterogeneity $\left(I^{2}=47.1 \%, p=0.003\right)$. Subgroup analyses were conducted according to tumour stage. The result indicated that decreased $\mathrm{Hb}$ had a prognostic impact on OS for patients in early stage (HR 1.81, 95\% CI 1.33-2.46), advanced stage (HR 1.60, 95\% CI 1.34-1.92) and both (HR $1.50,95 \%$ CI 1.37-1.64), although the heterogeneity was

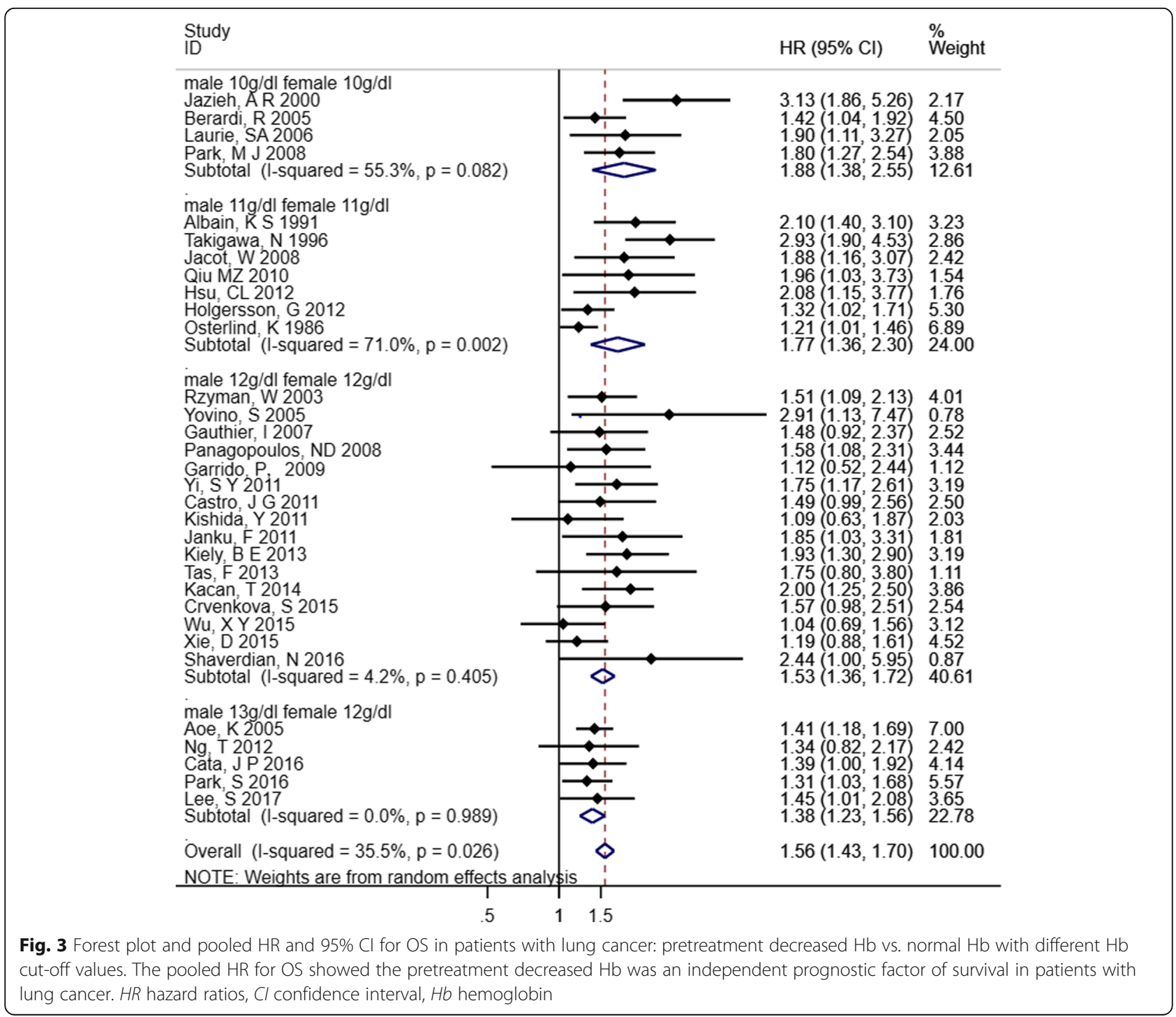




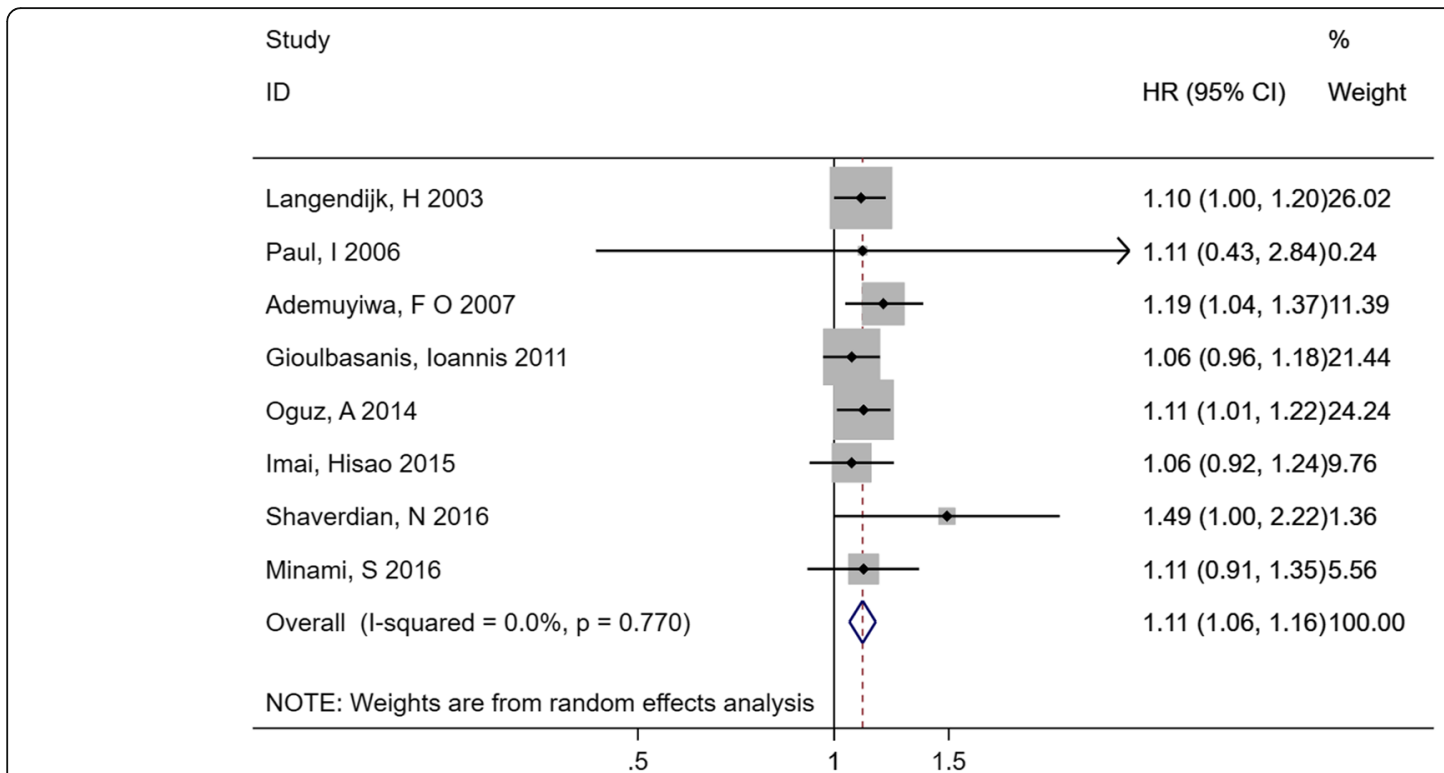

Fig. 4 Forest plot and pooled $\mathrm{HR}$ and $95 \% \mathrm{Cl}$ for the association between pretreatment $\mathrm{Hb}$ level (continuous variable) and OS in patients with lung cancer. The pooled HR indicated that decreased $\mathrm{Hb}$ was related to the poor OS. HR hazard ratios, $\mathrm{Cl}$ confidence interval, $\mathrm{Hb}$ hemoglobin

significant in the advanced stage subgroup $\left(I^{2}=70 \%, p=\right.$ 0.001) (Fig. 5).

\section{Prognostic impact of decreased $\mathrm{Hb}$ on patients with SCLC} Six cohorts with 3203 cases reported the data of pretreatment $\mathrm{Hb}$ (categorical variable: decreased $\mathrm{Hb}$ vs. normal $\mathrm{Hb}$ ) and OS in patients with SCLC. The pooled HR from the 6 cohorts showed that patients with decreased $\mathrm{Hb}$ were associated with shorter OS (HR 1.56, 95\% CI 1.21-2.02), although there was significant heterogeneity among the studies $\left(I^{2}=60.6 \%, p=0.026\right)$ (Fig. 6).

\section{DFS and decreased $\mathrm{Hb}$}

Three studies presented the data from their investigation of pretreatment $\mathrm{Hb}$ (categorical variable: decreased $\mathrm{Hb}$ vs. normal $\mathrm{Hb}$ ) and DFS. The combined data suggested that decreased pretreatment $\mathrm{Hb}$ was significantly correlated with DFS, with a pooled HR estimate of 1.98 (95\% CI 1.21-3.23) and no heterogeneity $\left(I^{2}=0.0 \%, P=0.419\right)$ (Fig. 7).

\section{RFS and decreased $\mathrm{Hb}$}

Three studies reported the correlation between RFS and decreased $\mathrm{Hb}$ (categorical variable: decreased $\mathrm{Hb}$ vs. normal $\mathrm{Hb}$ ). Interestingly, the pooled HR indicated that decreased pretreatment $\mathrm{Hb}$ was not significantly associated with shorter RFS (HR 1.37, 95\% CI 0.91-2.05), and the heterogeneity was not significant $\left(I^{2}=63.9 \%, p=0.063\right)$ (Fig. 8).

\section{Meta-regression analyses}

To further explore the potential causes of the heterogeneity, treatment method and sample size were used to conduct meta regression after the subgroup analysis. The results showed that these two factors were not the source of heterogeneity.

\section{Sensitivity analysis and publication bias}

In our meta-analysis, the Begg's funnel plot and Egger's indicator test were used to evaluate potential publication bias for OS. As our results show in Additional file 1: Figure S1 and Additional file 2: Figure S2, both the Begg's funnel plot and Egger's publication bias plot indicate the existence of publication bias among the included studies $(p<0.001)$. Interestingly, sensitivity analysis revealed that none of the HR point estimates lay outside the $95 \% \mathrm{CI}$ of the pooled analysis, which confirmed that our results were stable and reliable.

\section{Discussion}

Lung cancer is a leading cause of cancer death worldwide with about $15 \%$ of 5 -year survival rate [1]. It is well known that the TNM system has played an important role in the evaluation of clinical outcome and the decision-making process of selecting effective therapies. However, the complexity of its pathogenic mechanism means that the progression and prognosis of cancer can be caused by many factors. Patients with the same pathological stage often present with different outcomes, which suggests that the TNM system alone cannot precisely predict the survival of patients with lung cancer. Moreover, the TNM stage should be confirmed by biopsy; therefore, it is difficult to track stage changes in the process of cancer progression. Peripheral blood samples are easily obtained by nurses with less clinical practice cost. The current viewpoint considers that some 


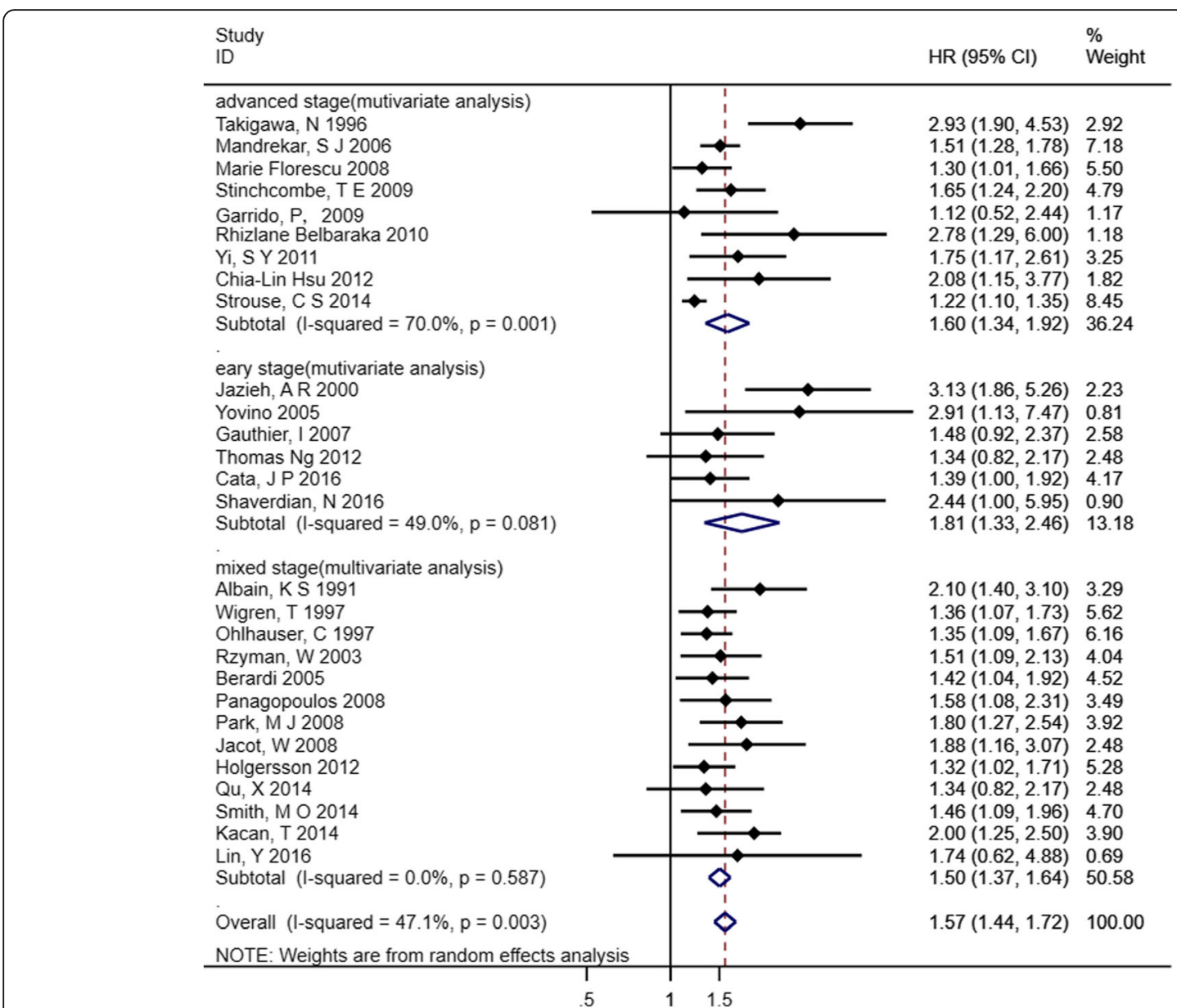

Fig. 5 Forest plot and pooled HR and 95\% Cl for OS in patients with NSCLC: pretreatment decreased Hb vs. normal Hb. The pooled HR for OS indicated that pretreatment decreased $\mathrm{Hb}$ level had a negative impact on survival of patients with NSCLC both in early stage and advanced stage. NSCLC non-small cell lung cancer, HR hazard ratios, OS overall survival, Cl confidence interval, Hb hemoglobin

haematological biomarkers are related to the prognosis of cancers, including the neutrophil to lymphocyte ratio [73], leucocyte [74], platelet [75], white blood cell [54] and $\mathrm{Hb}$ levels [76] before treatment. However, the prognostic value of the $\mathrm{Hb}$ level in patients with lung cancer remains controversial.

Many researchers aimed to develop a new evaluation or model to predict the expected lifetime of patients with lung cancer $[66,77]$. The creation of such instruments requires to identify the survival prediction value of pretreatment peripheral blood markers and other clinicopathological factors. $\mathrm{Hb}$ is an important hematological marker to predict the survival in patient with cancer. However, the prognostic value of decreased pretreatment $\mathrm{Hb}$ level on survival remains controversial. This systematic review and meta-analysis are the first evidence-based research to determine the prognostic impact of decreased pretreatment $\mathrm{Hb}$ on the OS, DFS and RFS of patients with lung cancer, which can make contributions to the personalized treatment programs.
In this systematic review with meta-analyses of 55 eligible studies, we first evaluated the relationship between decreased $\mathrm{Hb}$ and $\mathrm{OS}$ in patients with lung cancer. The results showed that patients with a $\mathrm{Hb}$ reduction at the time of diagnosis or before treatment were significantly associated with poor OS in both univariate and multivariate analysis. A significant heterogeneity was observed, but the pooled HRs were stable when deleting each study one by one. Thus, a random effect model was selected to analyse the pooled HR, and subgroup analyses and meta-regression were conducted. We also found that there were more studies of the prognostic value of decreased $\mathrm{Hb}$ in patients with NSCLC than in patients with SCLC. However, similar results confirmed that a decreased $\mathrm{Hb}$ level was a negative prognostic factor for OS in both patients with NSCLC and SCLC. Other survival indicators were also applied to this meta-analysis. Interestingly, different results were found for the prognostic value of preoperative $\mathrm{Hb}$ on DFS and RFS. As shown in Fig. 7 and Fig. 8, a decreased pretreatment $\mathrm{Hb}$ level was significantly associated 


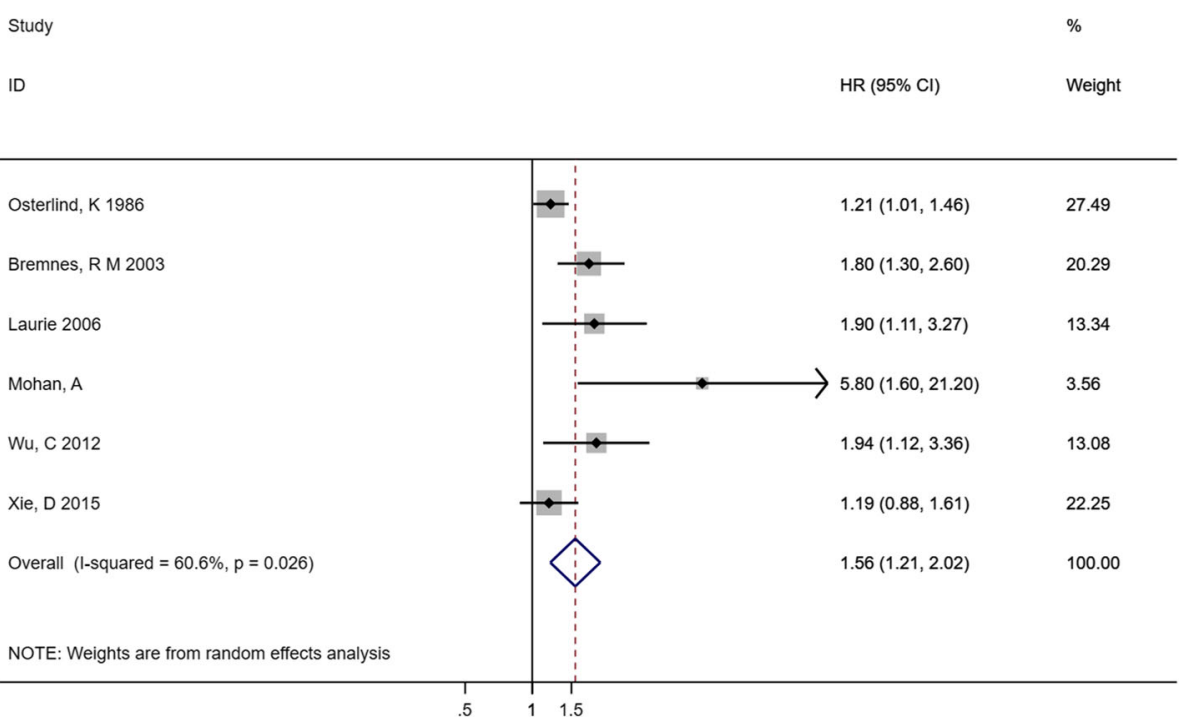

Fig. 6 Forest plot and pooled HR and 95\% Cl for OS in patients with SCLC: pretreatment decreased Hb vs. normal Hb. The pooled HR for OS showed decreased $\mathrm{Hb}$ level was associated with shorter OS. SCLC small cell lung cancer, HR hazard ratios, OS overall survival, Cl confidence interval, $\mathrm{Hb}$ hemoglobin

with poor DFS, while in three studies addressing RFS, the pooled $\mathrm{HR}$ indicated that the prognostic value of $\mathrm{Hb}$ was not significant. In the pooled analysis of the continuous variable $\mathrm{Hb}$ level and $\mathrm{OS}$, it can be postulated that, even if the $\mathrm{Hb}$ level was in the normal range, a lower $\mathrm{Hb}$ level was significantly associated with worse survival in patients with lung cancer.

The cause of $\mathrm{Hb}$ degradation is multifactorial and often relates to other comorbidities. It is reported that the systemic inflammatory responses from tumour cells strongly correlate with cancer progression and malignant transformation [78]. Specifically, interleukin-6 (IL-6) is an important inducer of the production of hepcidin, which is involved in iron metabolism. Elevated hepcidin levels lead to reductions in serum iron levels and result in decreased $\mathrm{Hb}$ [79]. It should be noted that higher hepcidin levels have been detected in patients with more aggressive diseases [79]. The mechanism underlying the prognostic value of decreased $\mathrm{Hb}$ in patients with lung cancer can be explained from several perspectives. $\mathrm{Hb}$ reduction contributes to hypoxia of tumour cells, which then stimulates tumour growth and increases the resistance

\begin{tabular}{|l}
\hline Shaverdian, $\mathrm{N}$ \\
Lin, $\mathrm{Y}$ \\
Overall (I-squared $=0.0 \%, \mathrm{p}=0.419)$
\end{tabular}




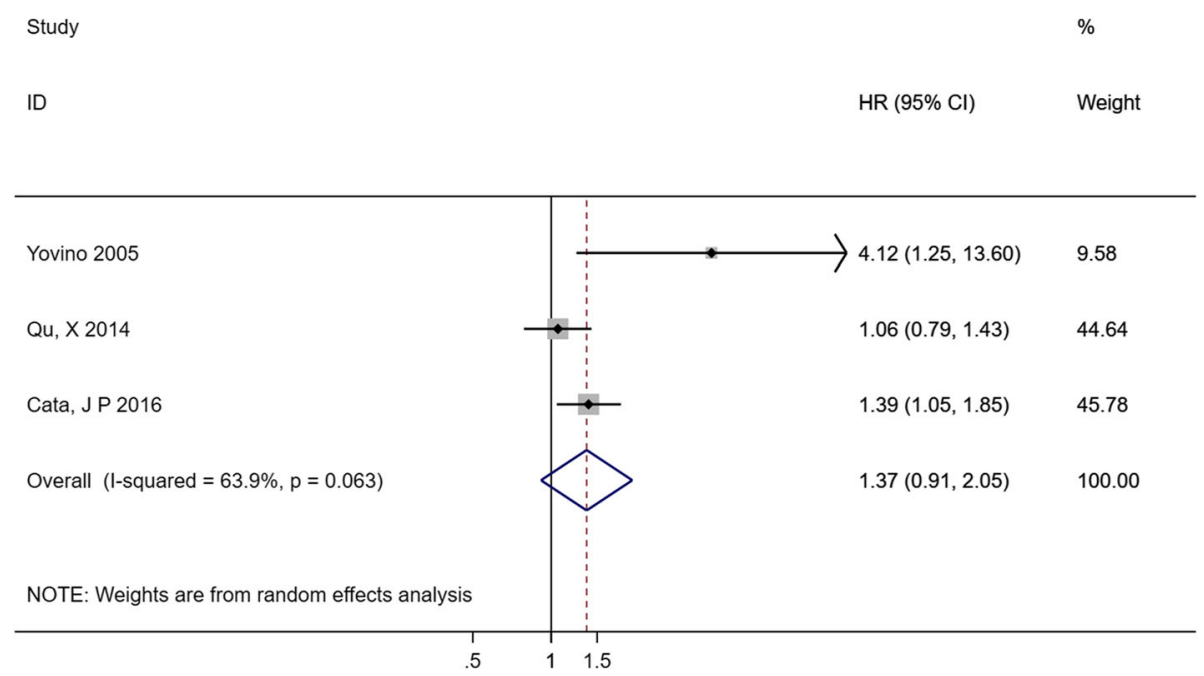

Fig. 8 Forest plot and pooled HR and 95\% Cl for RFS in patients with lung cancer: pretreatment decreased Hb vs. normal Hb. The pooled HR for RFS showed pretreatment decreased $\mathrm{Hb}$ level was not significantly associated with shorter RFS. HR hazard ratios, RFS relapse-free survival, Cl confidence interval, Hb hemoglobin

of tumour cells to radiotherapy and chemotherapy by regulating the gene expression and cell-cycle position, subsequently causing progression of cancer and shorter survival [80].

Two principal options for the management of decreased $\mathrm{Hb}$ have been proposed by previous studies, including the use of erythropoiesis-stimulating agents (ESAs) and blood transfusion [81]. ESAs could increase $\mathrm{Hb}$ levels and reduce transfusion requirements [82]. However, a meta-analysis of randomized controlled trials showed that the use of ESAs was associated with an increased risk of developing venous thromboembolism in cancer patients [83]. Therefore, the safety of treatment with ESAs in cancer patients still needs to be considered. Blood transfusion is effective for correcting $\mathrm{Hb}$ decline and improving symptoms or signs induced by decreased $\mathrm{Hb}$ in patients with cancer. However, it has been reported that perioperative blood transfusion was associated with an increased recurrence of lung cancer due to transfusion-related immunomodulation [84]. Overall, further studies are needed to investigate how to effectively manage decreased $\mathrm{Hb}$ in patients with lung cancer.

There are several limitations presented in this metaanalysis. First, the recruited data were extracted from observational studies, most of which were retrospective cohort studies; only two studies were based on prospective cohorts. Additionally, the cut-off values defining decreased $\mathrm{Hb}$ in our meta-analysis were not consistent, $10 \mathrm{~g} / \mathrm{dl}, 11 \mathrm{~g} / \mathrm{dl}, 11.5 \mathrm{~g} / \mathrm{dl}, 11.6 \mathrm{~g} / \mathrm{dl}, 12 \mathrm{~g} / \mathrm{dl}, 12.5 \mathrm{~g} / \mathrm{dl}$, $12.7 \mathrm{~g} / \mathrm{dl}, 12.8 \mathrm{~g} / \mathrm{dl}, 13 \mathrm{~g} / \mathrm{dl}, 13.1 \mathrm{~g} / \mathrm{dl}, 13.2 \mathrm{~g} / \mathrm{dl}, 13.6 \mathrm{~g} / \mathrm{dl}$, $14 \mathrm{~g} / \mathrm{dl}$ and $14.6 \mathrm{~g} / \mathrm{dl}$. This confounder may influence the outcomes. To strengthen the power of our results, studies with $10 \mathrm{~g} / \mathrm{dl}, 11 \mathrm{~g} / \mathrm{dl}, 12 \mathrm{~g} / \mathrm{dl}$ and gender-specific (male, $13 \mathrm{~g} / \mathrm{dl}$; female, $12 \mathrm{~g} / \mathrm{dl}$ ) cut-off values were analysed in the meta-analysis and similar results were obtained, specifically that decreased $\mathrm{Hb}$ was significantly associated with poor OS in patients with lung cancer. In fact, pooled results of the analysis of the continuous variable $\mathrm{Hb}$ and $\mathrm{OS}$ suggested that, even when the $\mathrm{Hb}$ level was within the normal range, lower $\mathrm{Hb}$ levels may predict the poor outcomes of survival and still need attention. Third, mild to moderate potential heterogeneity may exist between the included studies. We evaluated the prognostic value of $\mathrm{Hb}$ in NSCLC and SCLC separately. Subgroup analyses and meta-regression were conducted to detect the source of heterogeneity. Although the results suggested that region, subtype of lung cancer, treatment method and cut-off value were not the source of heterogeneity, there were still different features between the trials, and these features may be highly correlated and were not easily detected. Fourth, previous systematic review and meta-analysis showed that blood transfusions adversely affected cancer survival [85]. It was reported that the significant correlation between low $\mathrm{Hb}$ level and poor OS may be due to erythropoietin treatment or blood transfusion before surgery [86]. In our meta-analysis, since the data on how many patients received a blood transfusion during their survival time were not available, we cannot determine whether decreased pretreatment $\mathrm{Hb}$ or blood transfusion was the major factor of survival. However, this meta-analysis still explained the negative impact of decreased $\mathrm{Hb}$ on survival in patients with lung cancer to some extent. Further research on whether the decreased $\mathrm{Hb}$ levels before treatment directly affect the survival of patients with lung cancer, rather than blood transfusions, remains to 
be conducted. Fifth, there was significant publication bias for the correlation between decreased pretreatment $\mathrm{Hb}$ and $\mathrm{OS}$ in patients with lung cancer given the results of Begg's funnel plot and the Egger's test. The number of included articles was sufficient, but some of the baseline characteristics of the recruited studies differed in some confounders (gender, sample size, treatment, period of follow-up, etc.), which may contribute to the bias. We improved the stability of our estimation of the impact of decreased $\mathrm{Hb}$ on the prognosis of lung cancer by using sensitivity analysis. However, a publication bias still existed for the estimated pooled HR on OS. Finally, it was reported that not only did a lower Hb level lead to poor prognosis but abnormally elevated $\mathrm{Hb}$ did as well [87]. In this meta-analysis, we only focused on the impact of decreased $\mathrm{Hb}$ on survival, and further investigation and trials about the prognostic effects of abnormally elevated $\mathrm{Hb}$ on the survival of patients with lung cancer are needed.

\section{Conclusion}

In conclusion, our findings suggested that a decreased $\mathrm{Hb}$ level before treatment was a prognostic indicator of shorter OS and DFS both in patients with NSCLC and SCLC. The Hb level, an economical and readily available marker, might serve as an indicator for survival prediction, risk stratification and treatment selection. However, because of the limitation of our current study, additional large prospective cohorts and experimental trials are needed to confirm $\mathrm{Hb}$ level as an independent predictor of prognosis in patients with lung cancer. Additionally, targeting the correction of pretreatment $\mathrm{Hb}$ degradation may be an effective strategy to increase the survival rate of patients with lung cancer.

\section{Additional files}

\section{Additional file 1: Figure S1. Begg's funnel plot for included studies.} (JPG $75 \mathrm{~kb}$ )

Additional file 2: Figure S2. Egger's indicator test for included studies (JPG $69 \mathrm{~kb})$

\footnotetext{
Abbreviations

Cl: Confidence interval; DFS: Disease-free survival; EFS: Event-free survival; Hb: Hemoglobin; HR: Hazard ratio; MV: Multivariate; NCCN: National Comprehensive Cancer Network; NOS: Newcastle-Ottawa scale; NR: Not reported; NSCLC: Non-small cell lung cancer; OS: Overall survival; PFS: Progress-free survival; RFS: Relapse-free survival; SCLC: Small cell lung cancer; TNM: Tumor-node metastasis; TTP: Time to progression; UV: Univariate
}

\section{Acknowledgements}

Not applicable.

\section{Funding}

Not applicable.

\section{Availability of data and materials}

The datasets used and/or analyzed during the current study are available from the corresponding author on reasonable request.

\section{Authors' contributions}

YZ and PGW designed the systematic review; YQH, NJ, XNC performed the literature search and extracted the data; SQW and SYW evaluate the quality of included studies; YQH and PGW conducted the statistical analysis; YQH, $N J$, LJZ were involved in the interpretation of the results. YZ, PGW and NJ were responsible for the writing and critical revision of the manuscript. All authors read and approved the final manuscript.

Ethics approval and consent to participate

Not applicable.

\section{Consent for publication}

Not applicable.

\section{Competing interests}

The authors declare that they have no competing interests.

\section{Publisher's Note}

Springer Nature remains neutral with regard to jurisdictional claims in published maps and institutional affiliations.

\section{Author details}

${ }^{1}$ School of Nursing, Tianjin Medical University, Tianjin 300070, China. ${ }^{2}$ School of Nursing, Liaoning University of Traditional Chinese Medicine, Liaoning, China. ${ }^{3}$ Department of Radiotherapy, Tianjin Medical University Cancer Institute and Hospital, National Clinical Research Center for Cancer, Tianjin 300060, China.

Received: 7 July 2018 Accepted: 26 November 2018

Published online: 10 December 2018

\section{References}

1. Siegel RL, Miller KD, Jemal A. Cancer statistics, 2017. CA Cancer J Clin. 2017; 67:7-30.

2. Oser MG, Niederst MJ, Sequist LV, Engelman JA. Transformation from nonsmall-cell lung cancer to small-cell lung cancer: molecular drivers and cells of origin. Lancet Oncol. 2015;16:e165-72.

3. Diem S, Schmid S, Krapf M, Flatz L, Born D, Jochum W, Templeton AJ, Fruh M. Neutrophil-to-Lymphocyte ratio (NLR) and Platelet-to-Lymphocyte ratio $(\mathrm{PLR})$ as prognostic markers in patients with non-small cell lung cancer (NSCLC) treated with nivolumab. Lung Cancer. 2017;111:176-81.

4. Koh WJ, Greer BE, Abu-Rustum NR, Campos SM, Cho KR, Chon HS, Chu C, Cohn D, Crispens MA, Dizon DS, et al. Vulvar Cancer, version 1, 2017, NCCN clinical practice guidelines in oncology. J Natl Compr Cancer Netw. 2017; 15(1):92-120.

5. Ibrahim UA, Yusuf AA, Ahmed SG. The pathophysiologic basis of Anaemia in patients with malignant diseases. The Gulf journal of oncology. 2016;1: 80-9.

6. Cancer and chemotherapy-induced anemia. In: NCCN clinical practice guidelines in Oncology National Comprehensive Cancer Network 2011. http:// www.nccn.org/index.ASp Accessed 1 Aug 2011.

7. Baburao A, Narayanswamy H. Clinico-Pathological Profile and Haematological abnormalities associated with lung Cancer in Bangalore, India. Asian Pac J Cancer Prev. 2015;16:8235-8.

8. Buck I, Morceau F, Grigorakaki C, Dicato M, Diederich M. Linking anemia to inflammation and cancer: the crucial role of TNFalpha. Biochem Pharmacol. 2009;77:1572-9.

9. Caro JJ, Salas M, Ward A, Goss G. Anemia as an independent prognostic factor for survival in patients with cancer: a systemic quantitative review. Cancer. 2001;91:2214-21.

10. Li J, Chen S, Peng S, Liu Y, Xing S, He X, Chen H. Prognostic nomogram for patients with nasopharyngeal carcinoma incorporating hematological biomarkers and clinical characteristics. Int J Biol Sci. 2018;14(5):549-56.

11. Lin Y, Yang H, Cai Q, Wang D, Rao H, Lin S, Long H, Fu J, Zhang L, Lin P, et al. Characteristics and prognostic analysis of 69 patients with pulmonary Sarcomatoid carcinoma. Am J Clin Oncol. 2016;39:215-22. 
12. Strouse CS, Arce-Lara C, Whittle J, Santana-Davilla R. A retrospective, population-based comparison of pemetrexed and paclitaxel for first-line treatment of stage IV non-small cell lung cancer. Int J Radiat Oncol Biol Phys. 2014;90:S49.

13. Garrido P, Rosell R, Massuti B, Cardenal F, Alberola V, Domine M, Maeztu I, Ramos A, Arellano A. Predictors of long-term survival in patients with lung cancer included in the randomized Spanish lung Cancer group 0008 phase I trial using concomitant chemoradiation with docetaxel and carboplatin plus induction or consolidation chemotherapy. Clin Lung Cancer. 2009;10:180-6.

14. Kishida Y, Hirose T, Shirai T, Sugiyama T, Kusumoto S, Yamaoka T, Okuda K, Adachi M, Nakamura A. Myelosuppression induced by concurrent hemoradiotherapy as a prognostic factor for patients with locally advanced non-small cell lung cancer. Oncol Lett. 2011;2:949-55.

15. Stroup DF, Berlin JA, Morton SC, Olkin I, Williamson GD, Rennie D, Moher D, Becker BJ, Sipe TA, Thacker SB. Meta-analysis of observational studies in epidemiology: a proposal for reporting, Meta-analysis of observational studies in epidemiology (MOOSE) group. JAMA. 2000;283:2008-12.

16. Stang A. Critical evaluation of the Newcastle-Ottawa scale for the assessment of the quality of nonrandomized studies in meta-analyses. Eur J Epidemiol. 2010;25:603-5.

17. Cornell JE, Mulrow CD, Localio R, Stack CB, Meibohm AR, Guallar E, Goodman SN. Random-effects meta-analysis of inconsistent effects: a time for change. Ann Intern Med. 2014;160:267-70.

18. Higgins JP, Thompson SG. Quantifying heterogeneity in a meta-analysis. Stat Med. 2002;21:1539-58.

19. Egger M, Davey Smith G, Schneider M, Minder C. Bias in meta-analysis detected by a simple, graphical test. BMJ. 1997;315:629-34.

20. Liu JL. The role of the funnel plot in detecting publication and related biases in meta-analysis. Evid Based Dent. 2011;12:121-2.

21. Osterlind K, Andersen PK. Prognostic factors in small cell lung cancer: multivariate model based on 778 patients treated with chemotherapy with or without irradiation. Cancer Res. 1986:46:4189-94.

22. Albain KS, Crowley JJ, LeBlanc M, Livingston RB. Survival determinants in extensive-stage non-small-cell lung cancer: the southwest oncology group experience. J Clin Oncol. 1991;9:1618-26.

23. Takigawa N, Segawa Y, Okahara M, Maeda Y, Takata I, Kataoka M, Fujii M. Prognostic factors for patients with advanced non-small cell lung cancer: univariate and multivariate analyses including recursive partitioning and amalgamation. Lung Cancer. 1996;15:67-77.

24. Wigren $\mathrm{T}$, Oksanen $\mathrm{H}$, Kellokumpu-Lehtinen P. A practical prognostic index for inoperable non-small-cell lung cancer. J Cancer Res Clin Oncol. 1997;123: 259-66.

25. Ohlhauser C, Bülzebruck H, Ebert W, Drings P, Wannenmacher M. Prognostic factors for survival in inoperable non-small-cell lung cancer: a multivariate regression analysis of 456 patients with radiation therapy. Onkologie. 1997; 20:126-31

26. Jazieh AR, Hussain M, Howington JA, Spencer HJ, Husain M, Grismer JT, Read RC. Prognostic factors in patients with surgically resected stages I and II non-small cell lung cancer. Ann Thorac Surg. 2000;70:1168-71.

27. Rzyman W, Dziadziuszko R, Skokowski J, Wilimski R, Raiter A, Szymanowska $A$, Jassem $J$. The influence of blood transfusion on survival in operated nonsmall cell lung cancer patients. J Thorac Cardiovasc Surg. 2003;126:755-60.

28. Bremnes RM, Sundstrom S, Aasebo U, Kaasa S, Hatlevoll R, Aamdal S. The value of prognostic factors in small cell lung cancer: results from a randomised multicenter study with minimum 5 year follow-up. Lung Cancer. 2003;39:303-13.

29. Langendijk H, de Jong J, Wanders R, Lambin P, Slotman B. The importance of pre-treatment haemoglobin level in inoperable non-small cell lung carcinoma treated with radical radiotherapy. Radiother Oncol. 2003;67:321-5.

30. Tammemagi CM, Neslund-Dudas C, Simoff M, Kvale P. Impact of comorbidity on lung cancer survival. Int J Cancer. 2003;103:792-802.

31. Yovino S, Kwok Y, Krasna M, Bangalore M, Suntharalingam M. An association between preoperative anemia and decreased survival in early-stage nonsmall-cell lung cancer patients treated with surgery alone. Int J Radiat Oncol Biol Phys. 2005;62:1438-43.

32. Berardi R, Brunelli A, Tamburrano T, Verdecchia L, Onofri A, Zuccatosta L, Gasparini S, Santinelli A, Scartozzi M, Valeri G, et al. Perioperative anemia and blood transfusions as prognostic factors in patients undergoing resection for non-small cell lung cancers. Lung Cancer. 2005;49:371-6.

33. Pradier $\mathrm{O}$, Lederer $\mathrm{K}$, Hille A, Weiss $\mathrm{E}$, Christiansen $\mathrm{H}$, Schmidberger $H$, Hess CF. Concurrent low-dose cisplatin and thoracic radiotherapy in patients with inoperable stage III non-small cell lung cancer: a phase II trial with special reference to the $\mathrm{Hb}$ level as prognostic parameter. J Cancer Res Clin Oncol. 2005;131:261-9.

34. Aoe K, Hiraki A, Maeda T, Katayama H, Fujiwara K, Tabata M, Kiura K, Ueoka $\mathrm{H}$, Tanimoto M. Serum Hb level determined at the first presentation is a poor prognostic indicator in patients with lung cancer. Intern Med. 2005;44: $800-4$.

35. Mohan A, Goyal A, Singh P, Singh S, Pathak AK, Bhutani M, Pandey RM, Guleria R. Survival in small cell lung cancer in India: prognostic utility of clinical features, laboratory parameters and response to treatment. Indian J Cancer. 2006;43:67-74

36. Mandrekar SJ, Northfelt DW, Schild SE, Foster NR, Bot B, Marks RS, Mailliard JA, Krook JE, Maksymiuk AW, Adjei AA, et al. Impact of pretreatment factors on adverse events: a pooled analysis of north central Cancer treatment group advanced stage non-small cell lung cancer trials. J Thorac Oncol. 2006;1:556-63.

37. Laurie SA, Jeyabalan N, Nicholas G, MacRae R, Dahrouge S. Association between anemia arising during therapy and outcomes of chemoradiation for limited small-cell lung cancer. J Thorac Oncol. 2006;1:146-51.

38. Paul I, Lappin TR, Maxwell P, Graham AN. Pre-operative plasma erythropoietin concentration and survival following surgery for non-small cell lung cancer. Lung Cancer. 2006;51:329-34.

39. Gauthier I, Ding K, Winton T, Shepherd FA, Livingston R, Johnson DH, Rigas JR, Whitehead M, Graham B, Seymour L. Impact of Hb levels on outcomes of adjuvant chemotherapy in resected non-small cell lung cancer: the JBR 10 trial experience. Lung Cancer. 2007;55:357-63.

40. Ademuyiwa FO, Johnson CS, White AS, Breen TE, Harvey J, Neubauer M, Hanna NH. Prognostic factors in stage III non-small-cell lung cancer. Clin Lung Cancer. 2007:8:478-82.

41. Panagopoulos ND, Karakantza M, Koletsis E, Apostolakis E, Sakellaropoulos GC, Filos KS, Eleni T, Dougenis D. Influence of blood transfusions and preoperative anemia on long-term survival in patients operated for nonsmall cell lung cancer. Lung Cancer. 2008;62:273-80.

42. Park MJ, Kim HS, Jun HJ, Kim KH, Chang MH, Yi SY, Lee J, Park K, Ahn JS, Ahn MJ. Prognostic model to predict survival in patients with non-small cell lung cancer treated with gefitinib. Ann Oncol. 2008;19:viii111-2.

43. Jacot W, Colinet B, Bertrand D, Lacombe S, Bozonnat MC, Daures JP, Pujol $J$. Quality of life and comorbidity score as prognostic determinants in nonsmall-cell lung cancer patients. Ann Oncol. 2008;19:1458-64.

44. Florescu M, Hasan B, Seymour L, Ding K, Shepherd FA. A clinical prognostic index forpatients treated with erlotinib in National Cancer Institute of Canada clinical trials group study BR.21. J Thorac Oncol. 2008;3:590-8.

45. Stinchcombe TE, Hodgson L, Herndon JE, Kelley MJ, Cicchetti MG, Ramnath N, Niell HB, Atkins JN, Akerley W, Green MR, et al. Treatment outcomes of different prognostic groups of patients on cancer and leukemia group B trial 39801: induction chemotherapy followed by chemoradiotherapy compared with chemoradiotherapy alone for unresectable stage III nonsmall cell lung cancer. J Thorac Oncol. 2009;4:1117-25.

46. Belbaraka R, Tredan O, Ray-Coquard I, Chvetzoff G, Bajard A, Perol D, Ismaili $\mathrm{N}$, Ismaili M, Errihani $\mathrm{H}$, Bachelot $\mathrm{T}$, et al. Factors of interrupting chemotherapy in patients with advanced non-small-cell lung Cancer. BMC Res Notes. 2010;3:164.

47. Qiu MZ, Xu RH, Ruan DY, Li ZH, Luo HY, Teng KY, Wang ZQ, Li YH, Jiang WQ. Incidence of anemia, leukocytosis, and thrombocytosis in patients with solid tumors in China. Tumour Biol. 2010;31:633-41.

48. Ovcaricek T, Triller N, Sadikov A, Cufer T. Prognostic value of C-reactive protein and other classical factors in patients with advanced non-small cell lung carcinoma treated in routine clinical practice. Zdravniski VestnikSlovenian Medical Journal. 2010;79:669-76.

49. Yi SY, Ahn M, Park JY, Lee HR, Lee J, Park YH, Ahn JS, Park K. Prognostic factors in elderly patients with advanced non-small cell lung cancer treated with platinum-based doublet chemotherapy. J Clin Oncol. 2011;29:15.

50. Castro JG, TKTCRVFJBOFTYT, Hoff PM. Long-term follow-up of advanced nsclc patients treated with cisplatin-inorelbine. Eur Lung Cancer Conf. 2012; 7:S33-4.

51. Janku F, Tsimberidou AM, Wang X, Hong DS, Naing A, Gong J, GarridoLaguna I, Parsons HA, Zinner RG, Kurzrock R. Outcomes of patients with advanced non-small cell lung cancer treated in a phase I clinic. Oncologist. 2011;16:327-35.

52. Gioulbasanis I, Georgoulias P, Vlachostergios PJ, Baracos V, Ghosh S, Giannousi Z, Papandreou CN, Mavroudis D, Georgoulias V. Mini nutritional 
assessment (MNA) and biochemical markers of cachexia in metastatic lung cancer patients: interrelations and associations with prognosis. Lung Cancer. 2011;74:516-20.

53. Hsu C-L, Chen K-Y, Shih J-Y, Ho C-C, Yang C-H, Yu C-J, Yang P-C. Advanced non-small cell lung cancer in patients aged 45 years or younger: outcomes and prognostic factors. BMC Cancer. 2012;12:241.

54. Holgersson G, Sandelin M, Hoye E, Bergstrom S, Henriksson R, Ekman S, Nyman J, Helsing M, Friesland S, Holgersson M, et al. Swedish lung cancer radiation study group: the prognostic value of anaemia, thrombocytosis and leukocytosis at time of diagnosis in patients with non-small cell lung cancer. Med Oncol. 2012;29:3176-82.

55. Ng T, Ryder BA, Chern H, Sellke FW, Machan JT, Harrington DT, Cioffi WG Leukocyte-depleted blood transfusion is associated with decreased survival in resected early-stage lung cancer. J Thorac Cardiovasc Surg. 2012;143:815-9.

56. Wu C, Li F, Jiao SC. Prognostic factors for survival of patients with extensive stage small cell lung cancer-a retrospective single institution analysis. Asian Pac J Cancer Prev. 2012;13:4959-62.

57. Kiely BE, Veillard AS, Davidson JA, Trinkaus ME, Briscoe KP, Hughes B, Begbie S, Pavlakis N, Millward M, Boyer M, et al. Prognostic significance, accuracy and usefulness of oncologists' estimates of survival time for patients starting first-line chemotherapy for advanced non-small-cell lung cancer (ANSCLC). J Thorac Oncol. 2013;8:S880

58. Tas F, Ciftci R, Kilic L, Karabulut $S$. Age is a prognostic factor affecting survival in lung cancer patients. Oncol Lett. 2013;6:1507-13.

59. Qu X, Zhang T, Ma H, Sui P, J D. Lower mean corpuscular hemoglobin concentration is associated with unfavorable prognosis of resected lung cancer. Future Oncol. 2014;10:2149-59.

60. Smith MO, Sharkey AJ, George RS, Hubbard R, Rao J, Edwards JG. Prognostic implications of blood tests performed routinely prior to surgical resection of non-small cell lung cancer. Lung Cancer. 2014;83:S73-4.

61. Kacan T, Babacan NA, Seker M, Yucel B, Bahceci A, Eren AA, Eren MF, Kilickap S. Could the neutrophil to lymphocyte ratio be a poor prognostic factor for non small cell lung cancers? Asian Pac J Cancer Prev. 2014;15:2089-94.

62. Oguz A, Colak D, Ersoy U, Imamoglu IG, Altinbas M, Unal D, Zararsiz G. The effect of Haematological parameters on overall survival in advanced stage non small cell lung Cancer. UHOD-ULUSLARARASI HEMATOLOJI-ONKOLOJI DERGISI. 2014;24(2):82-8.

63. Crvenkova S. Prognostic factors and survival in non-small cell lung cancer patients treated with chemoradiotherapy. Maced J Med Sci. 2015;3:75-9.

64. Wu XY, Huang XE. Screening for patients with non-small cell lung cancer who could survive long term chemotherapy. Asian Pac J Cancer Prev. 2015;16:647-52.

65. Imai H, Kaira K, Mori K, Ono A, Akamatsu H, Matsumoto S, Taira T, Kenmotsu $H$, Harada $H$, Naito T, et al. Prognostic significance of diabetes mellitus in locally advanced non-small cell lung cancer. BMC Cancer. 2015;15:989.

66. Xie D, Marks R, Zhang M, Jiang G, Jatoi A, Garces YI, Mansfield A, Molina J, Yang P. Nomograms predict overall survival for patients with small-cell lung Cancer incorporating pretreatment peripheral blood markers. J Thorac Oncol. 2015;10:1213-20.

67. Abazari M, Gholamnejad M, Roshanaei G, Abazari R, Roosta Y, Mahjub H. Estimation of survival rates in patients with lung cancer in West Azerbaijan, the northwest of Iran. Asian Pac J Cancer Prev. 2015;16:3923-6.

68. Cata JP, Gutierrez C, Mehran RJ, Rice D, Nates J, Feng L, Rodriguez-Restrepo A, Martinez F, Mena G, Gottumukkala V. Preoperative anemia, blood transfusion, and neutrophil-to-lymphocyte ratio in patients with stage i nonsmall cell lung cancer. Cancer Cell Microenviron. 2016:3:e1116.

69. Shaverdian N, Veruttipong D, Wang J, Kupelian P, Steinberg M, Lee P. Pretreatment Anemia portends poor survival and nonlocal disease progression in patients with stage I non-small cell lung Cancer treated with stereotactic body radiation therapy. J Thorac Oncol. 2016;11:1319-25.

70. Park S, Park S, Lee SH, Suh B, Keam B, Kim TM, Kim DW, Kim YW, Heo DS. Nutritional status in the era of target therapy: poor nutrition is a prognostic factor in non-small cell lung cancer with activating epidermal growth factor receptor mutations. Korean J Intern Med. 2016;31:1140-9.

71. Minami S, Ogata Y, Ihara S, Yamamoto S, Komuta K. Outcomes and prognostic factors of chemotherapy for patients with locally advanced or metastatic pulmonary squamous cell carcinoma. Lung Cancer (Auckl). 2016;7:99-110.

72. Lee S, Eo W, Jeon H, Park S, Chae J. Prognostic significance of host-related biomarkers for survival in patients with advanced non-small cell lung Cancer. J Cancer. 2017:8:2974-83.
73. Yin $Y$, Wang J, Wang $X$, Gu L, Pei H, Kuai S, Zhang Y, Shang Z. Prognostic value of the neutrophil to lymphocyte ratio in lung cancer: a meta-analysis. Clinics (Sao Paulo). 2015;70:524-30.

74. Holgersson G, Bergqvist M, Nilsson J, Thureson M, Harmenberg J, Bergstrom S. The prognostic value of pre-treatment leukocytosis in patients with previously treated, stage IIIB/IV non-small cell lung Cancer treated with the IGF-1R pathway modulator AXL1717 or docetaxel; a retrospective analysis of a phase II trial. Asian Pac J Cancer Prev. 2017;18:1555-60.

75. Men H, Liang C, Yu M. Thrombocytosis as a prognostic factor in patients with renal cell carcinoma: a meta-analysis of literature. J Cancer Res Ther. 2015;11:67-72.

76. Barlas RS, Honney K, Loke YK, McCall SJ, Bettencourt-Silva JH, Clark AB, Bowles KM, Metcalf AK, Mamas MA, Potter JF, et al. Impact of hemoglobin levels and Anemia on mortality in acute stroke: analysis of UK regional registry data, systematic review, and Meta-analysis. J Am Heart Assoc: Cardiovasc Cerebrovasc Dis. 2016;5:e003019.

77. Rades D, Kaesmann L, Janssen S, Schild SE. A new score for estimating survival after definitive Radiochemotherapy of limited disease small cell lung cancers. LUNG. 2016;194(4):625-9.

78. Gardenghi S, Renaud TM, Meloni A, Casu C, Crielaard BJ, Bystrom LM, Greenberg-Kushnir N, Sasu BJ, Cooke KS, Rivella S. Distinct roles for hepcidin and interleukin- 6 in the recovery from anemia in mice injected with heatkilled Brucella abortus. Blood. 2014;123:1137-45.

79. Lefebvre T, Lasocki S, Feneant-Thibault M, Lamy PJ, Cunat S, Ropert-Bouchet M, Aguilar-Martinez P, Lehmann S, Delaby C. Added value of hepcidin quantification for the diagnosis and follow-up of anemia-related diseases. Ann Biol Clin (Paris). 2017;75:9-18.

80. Gaspar BL, Sharma P, Das R. Anemia in malignancies: pathogenetic and diagnostic considerations. Hematology. 2015;20:18-25.

81. Bormanis J, Quirt I, Chang J, Kouroukis CT, MacDonald D, Melosky B, Verma S, Couture F. Erythropoiesis-stimulating agents (ESAs): do they still have a role in chemotherapy-induced anemia (CIA)? Crit Rev Oncol Hematol. 2013;87:132-9.

82. Clark O, Adams JR, Bennett CL, Djulbegovic B. Erythropoietin, uncertainty principle and cancer related anaemia. BMC Cancer. 2002;2:23.

83. Zhan P, Wang Q, Qian Q, Yu LK. Risk of venous thromboembolism with the erythropoiesis-stimulating agents (ESAs) for the treatment of cancerassociated anemia: a meta-analysis of randomized control trials. Chin Clin Oncol. 2012;1:19.

84. Velásquez JF, Cata JP. Transfusions of blood products and cancer outcomes. Rev Esp Anestesiol Reanim. 2015;62:461-7.

85. Luan $H$, Ye F, Wu L, Zhou Y, Jiang J. Perioperative blood transfusion adversely affects prognosis after resection of lung cancer: a systematic review and a meta-analysis. BMC Surg. 2014;14:34.

86. Zhao F, Wang Y, Liu L, Bian M. Erythropoietin for cancer-associated malignant anemia: a meta-analysis. Mol Clin Oncol. 2017;6(6):925-30.

87. Berghmans T, Lafitte JJ, Thiriaux J, VanHoutte P, Lecomte J, Efremidis A, Koumakis G, Giner V, Richez M, Corhay JL, et al. Survival is better predicted with a new classification of stage III unresectable non-small cell lung carcinoma treated by chemotherapy and radiotherapy. Lung Cancer. 2004;45:339-4.

Ready to submit your research? Choose BMC and benefit from:

- fast, convenient online submission

- thorough peer review by experienced researchers in your field

- rapid publication on acceptance

- support for research data, including large and complex data types

- gold Open Access which fosters wider collaboration and increased citations

- maximum visibility for your research: over $100 \mathrm{M}$ website views per year

At BMC, research is always in progress.

Learn more biomedcentral.com/submissions 